\title{
Designing the city from public space. A contribution to (re)think the urbanistic role of public space in the contemporary enlarged city
} Rodrigo Coelho Universidade do Porto, Portugal

Centro de Estudos de Arquitectura e Urbanismo, Faculdade de Arquitectura rodrigo.coelho@arq.up.pt

\begin{abstract}
Considering the tendency for expansion, diversification and fragmentation of the present city's urban spaces, and considering that in the last decades public space lost much of the formal and functional attributes that it held in the past (in the historical city), the main problem that we currently face as architects and planners, seems to be how to articulate and (re) build (new) public places that materialise, in a qualified manner, the collective experience (the new ways of living, social interaction and displacement) of the "newer parts" of the city, and that simultaneously incorporate attributes that transform them into memorable and perennial spaces landmarks of the city that is to come.

The recent practical and theoretical outputs contradictorily appear to demonstrate a relative devaluation of the structuring role of public space, especially in those less consolidated parts of the city. Regarding the architectonic and urbanistic practice, we conclude that, in a time of mediatisation of architecture (in particular by the enhancement of the image and of iconographic values), the construction of the city and the materialisation of public space expresses, in many cases, generic and epidermal responses with visible consequences in terms of urban structure and perception of the city. Regarding the theoretic outputs, the insights also do not appear, in general, to contribute towards a theoretical framework committed to a consistent practical knowledge, or the resolution of the key issues and challenges that the city faces today.

Taking into account these considerations, and starting with a brief diagnosis that will focus on the major "weaknesses or controversies" that we identify in the theoretical discourse on the city and on public space, this paper will seek to focus on the importance of the urbanistic vocation of public space by identifying three main issues or key purposes to think and retrieve the public space project in the contemporary city. The three key purposes that will help us to recognize the strategic importance of public space in the contemporary European "enlarged city", and that will be analysed by using a case study, are:

- the public space as an ordering element of "new urban expansion";

- the public space as a factor of reconstruction of the "city without a plan";

- the public space as a (re)structuring element of the "metropolitan city".
\end{abstract}

Keywords: public space; landscape; contemporary city; urban project; urban regeneration.

To cite this article:

Coelho, R. (20I7). Designing the city from public space. A contribution to (re)think the urbanistic role of public space in the contemporary enlarged city, The Journal of Public Space, 2(I), 95-108,

DOI: $10.5204 / j p s . v 2 i 1.53$

This article has been peer-reviewed and accepted for publication in The Journal of Public Space. Please see the Editorial Policies under the 'About' section of the journal website for further information.

This work is licensed under a Creative Commons Attribution - Non Commercial 4.0 International License. https://creativecommons.org/licenses/by-nc/4.0/ 


\section{Introduction}

This article presented under the title "Designing the city from public space. A contribution to (re)think the urbanistic role of public space in the contemporary enlarged city" is, fundamentally, a reflection on the plausibility of the project of public space to constitute itself as an instrument and factor of structuring and designing of the city. In relation to this issue, we can see different approaches. On the one hand, we identify a trend that faces the project of public space as "medicine for all ills that the city suffers", which we can see reflected in a theoretical discourse and in a professional practice (the last one mainly surrendered to the seductiveness of fashions and architectural icons).

On the other hand, it is possible to recognise another approach based on a critical understanding of the role of the project of public space, which drifts from the recognition of the subjectivity and arbitrariness that many recent interventions in the city and public space translate (and which require a disciplinary refocusing on the problem of public space design).

A third understanding of this topic can be recognised on the devaluation of the role of the project and of the urban importance of public space in the current city, assuming it as a generic and diffuse entity. This understanding converges with extra-disciplinary approaches (especially those arising from humanities and social sciences, but also from the visual and performing arts) that explicitly or implicitly, "invoke" the loss of urban and architectural vocation of the public space, which consequently leads to understand the project of public space as a "impossibility".

In terms of theoretical discussion, we can find the origin of these cleavages, both in a certain emptiness or loss of disciplinary identity that affects architecture from the second post-war period (which it is not indifferent to the cultural crisis that is clearly mirrored in the urban strategies and policy management of our cities), both in the loss of influence of the paradigm that dominates the design and project of public space - embodied in the Barcelona model - which lasted until the mid-90s.

Simultaneously we witnessed in the last decades the assimilation and integration of extradisciplinary contributions in the public space discourse, mainly in an abstract and reductive manner, submerging the criticism, the "theory" and practice around the public space and the city in a kind of Babel, prevailing a speculative "abstract" discourse. In our view, these speculative and "abstract" discourses do not seem to construct a solid theoretical basis, capable of serving a consistent practical knowledge, and capable of solving the key issues and challenges that the city currently faces.

This paper appears, therefore, amidst a crossroad of concepts, contradictions and uncertainties (concerning the city and public space) that tend to weaken the disciplinary point of view, not only the theoretical and practical knowledge (regarding architecture and urban design), but also the role of the architect and architecture, in the materialisation of the common collective habitat, particularly in those less consolidated urban areas, in which the intervention of architects and urban planners is surely decisive in the structuring of today's cities.

But our approach to these topics do not deny or refuse the greater complexity and greater uncertainty with regard to city and public space's construction processes and dynamics; on the other hand, this reflection takes into account, at its base, a set of disciplinary premises or assumptions that frame not only the objectives and our observation point, but also allows us to rank the priority of the problems and to prioritise the theoretical and 
methodological issues.

As an initial proposition, we assume that the urban project and public space design must be firmly anchored in the idea of "built matter" - endowed with purposes and accurate and meaningful shapes - that we continue to link with the concept of public space.

Secondly, we believe that on the basis of "projects and programs of urban reconstruction" in the enlarged contemporary city, public space (understood either as a singular space in the city, either as an urban system) continues to have a central role to play in the "design of the city" and can provide structure, shape and identity to dispersed and disqualified urban sectors.

The third proposition that guided this paper is thus reflected on the need to consider interventions that (starting from a global perspective) can develop and materialise a detailed scale, overcoming the abstract visions and working methods of planning.

These hypotheses, or beliefs, put us on the trail of authors, architects and planners such as Carlos Marti, Vittorio Gregotti, Oriol Bohigas, Manuel de Solà-Morales or Joan Busquets, who claim, not only in theory, but also through the design practice, the importance of expressing purposes, "ideas of architecture" and "ideas of city", according to our own discipline criteria and attributes.

This paper takes as a specific field of research the Portuguese reality, considering that the Portuguese context - its scale and its idiosyncrasies - is not invulnerable to the change of paradigm and the contradictions and weaknesses pointed above, concerning the role of public space, and in particular the role of urban design in the context of recent changes. The delineation of a possible "map of key design approach issues" emerges as the central aim of the paper, a "map" capable of giving consistency to the project practice, considering the public space (new or reclassified) as a factor of rebalancing / restructuring of a city that grew fragmented and discontinuously during the second half of the twentieth century. Besides this general objective, this paper aims to:

- Assess the relevance and capacity of the (designed) public space to solve concrete problems and its ability to assign structure, identity, and a symbolic and formal order to the above mentioned urban sectors, fulfilling at the same time the desires and uses that the contemporary society claims to public spaces;

- Assess whether current strategies and design methodologies and the new public space configurations of the recent city (in many cases linked to infrastructure, mobility systems, or community facilities), (yet) may or may not take into account architectural and urbanistic criteria (structure, scale, shape, use) that were the basis of the design of public spaces of the canonical city (where we can recognise an identity, intensity of use, which we do not found in the new parts of the city);

- Inquire about the cultural, social and economic circumstances, in which the practice of the public space project is today inscribed, in order to understand how can we consider the project as an ordering tool (able to qualify the experience of perception, and readability of urban space) and, on the other hand, as a factor of consistency and integration of the different disciplines and interests (often conflicting) that converge in the public space.

\section{The "Ioss" of architectural and urban vocation in the construction of public space}

During this time of uncertainty, when we hear about the imminent death of public space, of 
the retreat towards the private, of rising fear and insecurity instilled by the city, it comes as altogether surprising - even paradoxical - the sheer number of studies and interventions that focus exactly on public space as their specific field of action. Perhaps it could then be argued that never before has as much been required and expected from public space; never have so many interventions and requalifications been effected as public space; and certainly never much thinking and theorising addressed public space.

Conversely, this paradoxical reality hints at a set of contradictions, which, we believe can become significant to the discernment of prevailing key issues, intersecting within a broader reflection on public space design, urban design, and architectural practise.

For instance, the lack of consensus bred amongst the different disciplines that effectively build public space (architecture, landscape architecture, engineering) remains paradoxical, as to what meaning should be assigned to this space, its shape, and what role might public space play in city-building today.

Enforcing adulterated values and concepts, whilst namedropping politically correct slogans "ecology", "environmental", "sustainability" -, most of the latest public space proposals (and particularly those of the last two decades) seem to follow design recipes - generic strategies that present, largely, a blatant spatial and figurative standardisation. Moreover, these guidelines entail a simplification or outright dismissal of urbanistic and architectural methodologies and criteria, which were historically held as fundamental to the conception of public space.

Likewise, the enforcement of dissonant programs, that are ill fitting in their surrounding urban realities (either due to their artificial complexity, strictly-functional design guidelines, or marketing-oriented intents, prompted by the ever-increasing demand of entertainment and comfort by the user), characterises an overall generic method of building public space today.

In this sense we will agree with Manuel de Solà-Morales, when he criticises this approach as "(...) a new form of autonomous professional practice, which sees the precinct where the work is to be done as a free range in which zero-elevation architecture might be invented, an unconstrained exercise, in which - relatively - low-cost forms and images can be explored in freedom that could not exist in construction that is constantly submitted to the much stricter requirements of the programme, costs, functions, structure and client"'. With its conception seemingly void of strategic insight, this designed public space often results in an unarticulated arrangement of isolated parts - usually self-referential, structurally fragile, undefined in use and scale - leading to the diffusion of meaning and legibility of public space and urban form, detaching it from the tectonic and urban condition that we typically assign to that space.

This feebleness, which is diagnosed as inherent to this public space, attunes to the nonsustainability of long-term urban design decisions, given the complex interplay of power relations and stepped decision-making processes that make up the management of the city of today. According to Nuno Portas, our time is one of amplification of technical solutions and cultural patterns, which in turn compromise a technical, cultural, and disciplinary consensus in the establishment of architectural and urbanistic models to city-(re)building; this is particularly relevant to the relationship between the public space's outline and urban fabric, which is decisive to a coherent urban layout ${ }^{2}$.

These mounting inconsistencies, induced by a loss of architectural and urbanistic insight into planning public space, turns the greatest part of the recently built public space architecture, 
into a multi-referenced and diffuse entity, devoid of a discernible typological or spatial matrix, and ultimately unable to express civic, aesthetic, functional and social meanings. While it is true that this dismal diagnosis can - and should - be nuanced according to each situation in its singular context, we must also recognise that, considering its repercussions to the city, these different approaches to public space design, in our disciplinary area, fail to take into account the structural support matrix that, in the past, guided the construction of public space, ensuring its stability, permanence, and continuity.

Considering the enduring urban deficit, even in the city sectors we have seen growing in the last decades, and faced with the inconsistencies and unseemliness of these (new) public spaces, it becomes as necessary as it is urgent to question their outset purposes, design practices and methodologies, thus allowing us to implement a positive reaction to the problem of (re)building public space in the contemporary city.

This means that, given the present urban reality (as staged in most European cities), we believe that it becomes significant to wonder: how feasible is it to shape the city nowadays? In what way can we or should we act, considering how challenging it is to control its overall shape and structure? What instruments must we wield to do so? What role does public space play, in a more desirable prospective process of city redesigning?

\section{Thinking public space in the contemporary city}

The need to think public space as the main pillar of city-building

Given the penchant for expansion, diversification, and fragmentation of the urban open space in the city of today, a critical issue seems to arise for us, architects and urban planners, as to how best to mediate coexistence amid the great diversity of our urban places; and thence, from our public spaces, materialise renewed social interactions and new ways of living and commuting.

Moreover, if the designed public space has indeed lost much of its historical formal and functional attributes, as previously stated, how then can we (re)build (new) public places that render the collective existence of a city, while simultaneously embodying attributes that may convert them into suitable, memorable, permanent spaces? Or, as Carlos Martí notes, how can we (re)build (new) public places as "landmarks of the city to come"? Following Carlos Martí, these two issues relate to the incurring difficulty to describe the "public places of our time"; furthermore, they seemingly converge into one nuclear concern regarding the uncertainty of what is - or should be - the contemporary city. Believing these to be two facets of one singular problem, Martí notes that "(...) the presence of public places is what characterises the city itself and what makes it different from a mere settlement (...)"3.

The need to consider the idea of 'City' as a mean to think public space becomes, in this way, quite decisive. From our point of view, and following Marti's argument, it is only possible to meaningfully discuss public space by having it assuming a role and value that are interdependent of architectural and urbanistic attributes of the physical and cultural aspects pertaining to the urban context, in which it operates.

With this in mind seem the arguments of Jordi Borja and Oriol Bohigas even more relevant, as both authors underline the necessary challenge of "making city over the city" (by perceiving the present city as a set of potentially rebalancing social and territorial centralities), recognising the recovery of the city, urban mobility, urban fabric, and, aptly enough, 
public space, as main subjects to address in that challenge ${ }^{4}$. We are therefore interested in a city model that allows public space an inter-mutual value, so this might be a product of interdisciplinary action, and where public space design, urban design, and urban planning can be instrumental in its development.

The need to think and design the city and its public spaces from accurate scale referents The lack of correlation between scale referents and assigned fields of study seems one of the most evident methodological shortcomings displayed in current theoretical approaches to public space, what can only produce studies and reasoning that are borderline with the abstract, generic, and inconclusive.

If we can agree that today's cities seem to share the same widespread symptoms, we believe that a more in-depth study of public space in the contemporary city must then be specifically framed within a pre-set reality and order of magnitude. This seemingly simple premise becomes decisive, given that most of the speculation and conjecture surrounding the debate of "public space in the contemporary city" tend to be based on assumptions that are only pertinent in very specific contexts (such as in large cities or metropoles) - as these conjectures turn to guidelines, they become the prevailing discourse, take on an official value, and ultimately impede more consistent research on public space.

In a time when it seems that the concept of city has broaden up, where the city itself becomes dissolved into the city-region, it is significant to note that the European territory is not composed of large cities or conurbations, but of medium to small-sized cities. For this reason, the pre-set of an order of magnitude (and, thus, of a concrete field of study) is in itself a powerful statement of principles, regarding the value (the premise, the objective, the intent) afforded to what we perceive as a city or public space today. We believe this assertion to be crucial if we intend public space to partake in the debate of urban issues - a debate in which remains pertinent to think city and public space on criteria of form, structure and meaning.

The need to think and design the city beyond its consolidated limits Yet, predictably, the contemporary city - even the medium-sized one - breeds such an array of issues, that their very complexity and diversity provoke equally complex and diverse opinions in its public space. We believe that the main concern should relate to the ascertainment of the sector or sectors of the city where intervention on public space becomes urgent or problematic.

As Nuno Portas notes, in the numerous requalification and regenerative interventions of the $80 \mathrm{~s}$ and $90 \mathrm{~s}$ (targeting central and preeminent areas of the city), public space is given a key role, perceptibly holding a certain status. On the other hand, this same status is not apparent in those interventions developed in the limits, in the outskirts of the emerging city, i.e., in the open and discontinuous city, where we sorely lack, in number and quality, urban concepts and strategies, that may help define consistent paradigms by which to act. We believe this to be a consequence not only of the lack of a more comprehensive and integral city-wide proposal, but of the likely resistance, in architectural and urbanistic disciplines, in complying with any necessary and inevitable losses and paradigm shifts, that come with the transition to a more heterogeneous and open urban reality. We are thus in need of models and strategies by which to think and act upon the outmost, less consolidated urban areas, which is where the 'future of the city' takes place nowadays, 
and where reflections on the conceptualization and materialisation of the public space become increasingly demanding.

We do recognise, additionally, that the current theoretical debate on the city and public space (within our discipline) has often been swayed by the bipolarization between the good and bad city, between the good and bad public space, which usually leads to strict and dogmatic assertions regarding the interpretation and ability to intervene in the city, and design its public spaces.

Therefore, it is not uncommon to find polarized viewpoints, between those who call for a mimetic (albeit uncritical and reductive) return to the more legible and reassuring types of the traditional city - the public space characterised by a nostalgic and outdated architecture, preached and enforced in the new urbanism à la Krier (as Nuno Portas remarks) - and the proponents of a city without form, generic and indomitable, that denies public spaces their ordering vocation, their ability to commit standards of clarity, order, and hierarchy to urban space.

Public space as a design problem: the need for purposes, while intervening in the city from public space

As Bernardo Secchi rightly points out, "(...) the image of the contemporary city is a city that already exists, but is waiting for a project."5. By developing this idea, Carlos Martí suggests that this project is not only an inquiry into the meaning of things, but also an intellectual procedure, allowing us to operate on the world whilst understanding it ${ }^{6}$.

Following these arguments (and recalling those aforementioned, urging a strategic significance and concrete city size as premises in interpreting and planning public space), we believe a more rich and operational research of urban reality to be possible, granted we can select those spaces, places, and projects that are adept to condense the urban design issues that affect the city as a whole.

For an increasingly comprehensive, accurate analysis and intervention in the public space of the contemporary European city, we would propose as a starting point hypothesis the pressing need to further investigate, selectively, those areas of the city (perchance of different scale, form, and use) that allow us to perceive them as prospective ordering elements of urban form, and potentially significant spaces in a collective experience of the city.

This hypothesis must therefore be understood as a comprehensive analysis matrix that is also selective or multi-targeted, allowing for the identification of 'vectors' and 'topics of analysis' that we deem relevant to a re-valuation of urban insight in the projects of public space ${ }^{7}$.

From this set matrix, we simultaneously recognise both the recurrence of the same invariable themes, and the contemporary city with its different parts, as projects in themselves, apt to be tackled as specific and concrete problems within a different reality (like Bernardo Secchi and Carlos Martí suggest); therefore, we believe that a clear distinction of three main purposes or problems for public space is fundamental:

- the public space as an ordering element of urban expansion;

- the public space as a reconstructive element of the unplanned city;

- the public space as a restructuring element of the metropolitan city.

These three purposes (which are attuned to more operative topics of analysis, and specific project-related issues) are not established just as statement of principle, in recognising the 
importance of public space in the current city; they also allows us, from the outlook of design and analysis, to individualise and clarify the assorted roles that, in our view, public space can or should fulfil.

Furthermore, in terms of methodology, we believe that it is important to distinguish the intermediate urban design scale as the more consistent and appropriate approach, while intervening in the city through public space ${ }^{8}$. As stressed by Manuel de Solà-Morales (when highlighting the long tradition of urban design), this approach consists in operating "(...) from the geography of a given city, on its requests and suggestions, and, with architecture, introduce language elements that shape the site (...) it is also working inductively, generalizing the particular, the strategic, the local, the generative, and the model"'.

\section{Designing public space of the contemporary enlarged city. A paradigmatic example: the Metro do Porto project}

Now that we identified the key issues and purposes that we believe are crucial to think the design of public space in the contemporary enlarged city, we are able to point out concrete examples, which aim to make our interpretation grid, and also the reflection undertaken so far more understandable and operative.

We could address these issues separately, using different examples; however we have chosen to recognise these urbanistic purposes for the public space project, integrated into a single one - the $I^{\text {st }}$ phase of the Metro do Porto project (coordinated by Eduardo Souto de Moura 1999 and 2008) - which largely agglutinates, on its proposal, the three abovementioned main purposes.

This proposal refers to a metropolitan scale intervention, which consists of a set of (re) designed public space projects which, in the medium and long term, share the recognition of the structuring importance of public space in the central and peripheral city, and reveals the opportunity to regenerate some sectors of the city and allows to (re) design the city outside the so-called traditional city.

This means that we are before a set of interventions that underline the possibilities and responsibilities that a conscious and consistent control of the disciplinary tools of architecture and urbanism may acquire in the (re) structuring (and transformation) of the city and territory in their unstable and less structured sectors.

From a more particular view, this project allows us to highlight the potential of these (public) spaces, that are endowed of an infrastructural base, in defining the morphology of the city and its less consolidated public spaces, by rescuing a previously absent social, architectural or even landscape dimension.

While integrating other undertaken or planned urban projects for the city, the Metro do Porto project was set up as a potentially "re-structuring" and "repairing" system, which comprised nodal points and linear centralities of varying importance. In this sense, it was able to enhance a wider urban transformation of the city, and made possible the recognition of a new civic space and of a new dimension to the whole metropolitan territory.

In order to put the origin of this intervention into context, it should be noted that the main motivation for implementing a project with such characteristics was due, in this case, to the need to solve structural mobility (and public transport) problems within the metropolitan area of Porto, which is largely dependent on private transportation. These problems have become worse over the past decades, with the exponential increase of the use of the 
private car, causing difficulties in traffic movement and parking, both in the city centre, and in the city's main accesses and exits.

However, the intervention of the Metro in the Porto Metropolitan Area demonstrates, very clearly, not only the ability of this mobility network to confer (from a strategic and functional point of view) some "territorial balance" to a polycentric and dispersed metropolitan structure, but also shows a great potential for transformation and regeneration of the urban spaces that are crossed by this mobility network.

This urbanistic potential is undoubtedly related to the undertaken technical option (light rail surface Metro - tram) which thus offered the possibility of establishing links between distant and disconnected urban sectors, which, under the conception of an integrated urban project (the $70 \mathrm{~km}$ of constructed line, and the 69 stations built, give a clear idea of the magnitude and potential of the urban and territory spatial transformation within the Porto metropolitan area).
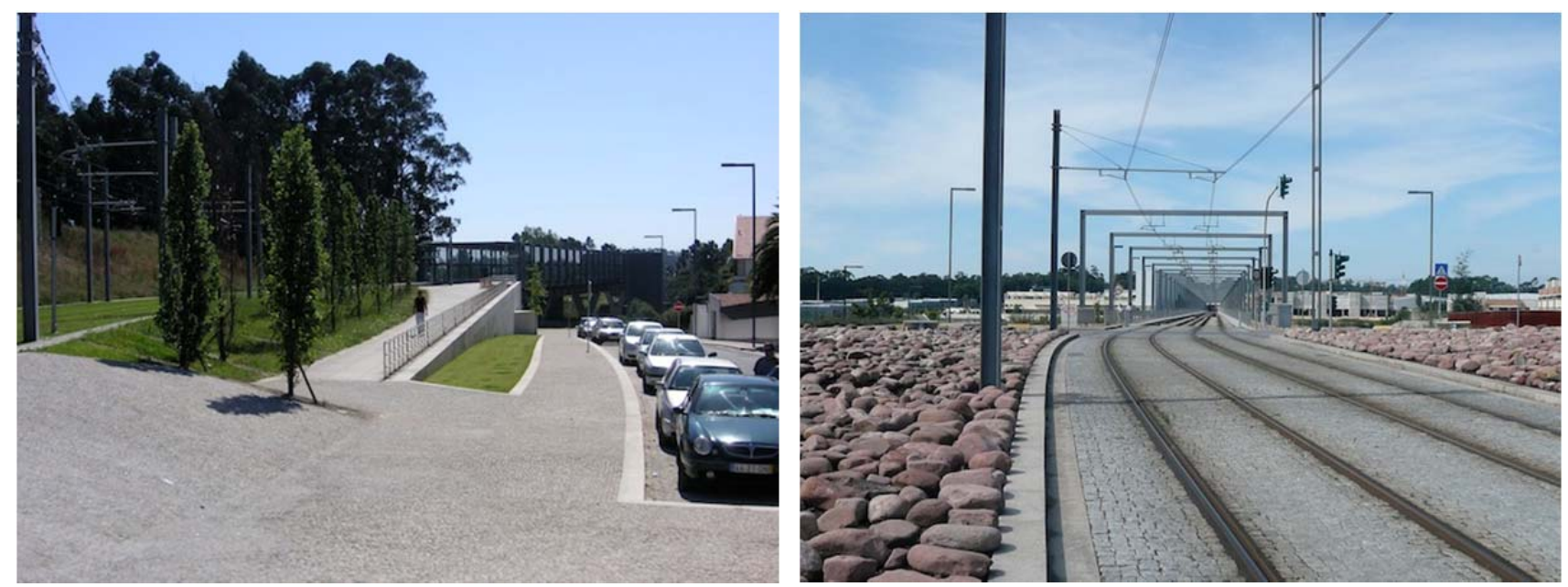

Fig. I-2. Metro do Porto interventions in Maia. Eduardo Souto de Moura and João Álvaro Rocha Source: author.

Therefore, it is possible to observe coherence and balance on the general characterisation of the reconfigured urban surfaces, which are perceived as parts of a common and comprehensive urban design that spreads across the enlarged city.

To some extent, this concern recalls the role of the ("domesticated") infrastructure as a fundamental tool for public space restructuring in the enlarged city, since, by proposing an overall design for the infrastructure, for the city and for the territory, the Metro o Porto intervention embodies a concrete and conciliatory response to a more fragmented and diffuse urban reality.

It can thus be said that this project clearly avails the benefits that are commonly associated with the implementation or conversion of an infrastructure (which are reflected in the possibility of redesigning parts of the city and of the territory, as it involves, in many cases, earthworks, resetting accesses, expropriations, etc.). That is to say, by acting as a second nature, the infrastructure of the light tram is able to polarise activity around it, and redesign, at a territorial and urban scale, the crossed public spaces.

In other words, unlike a substantial part of the road infrastructure that serves the peripheral areas of the Porto Metropolitan Area, the construction of a spatial system like 
the Metro do Porto confers richer and more articulated relationships among the different types of uses and urbanisation patterns of the territory (which in most cases are incongruously and sparsely disposed in the city), allowing for the strengthening, in some strands of the tram line, of new "canal areas", or main structural axes in the future Porto Metropolitan Area.
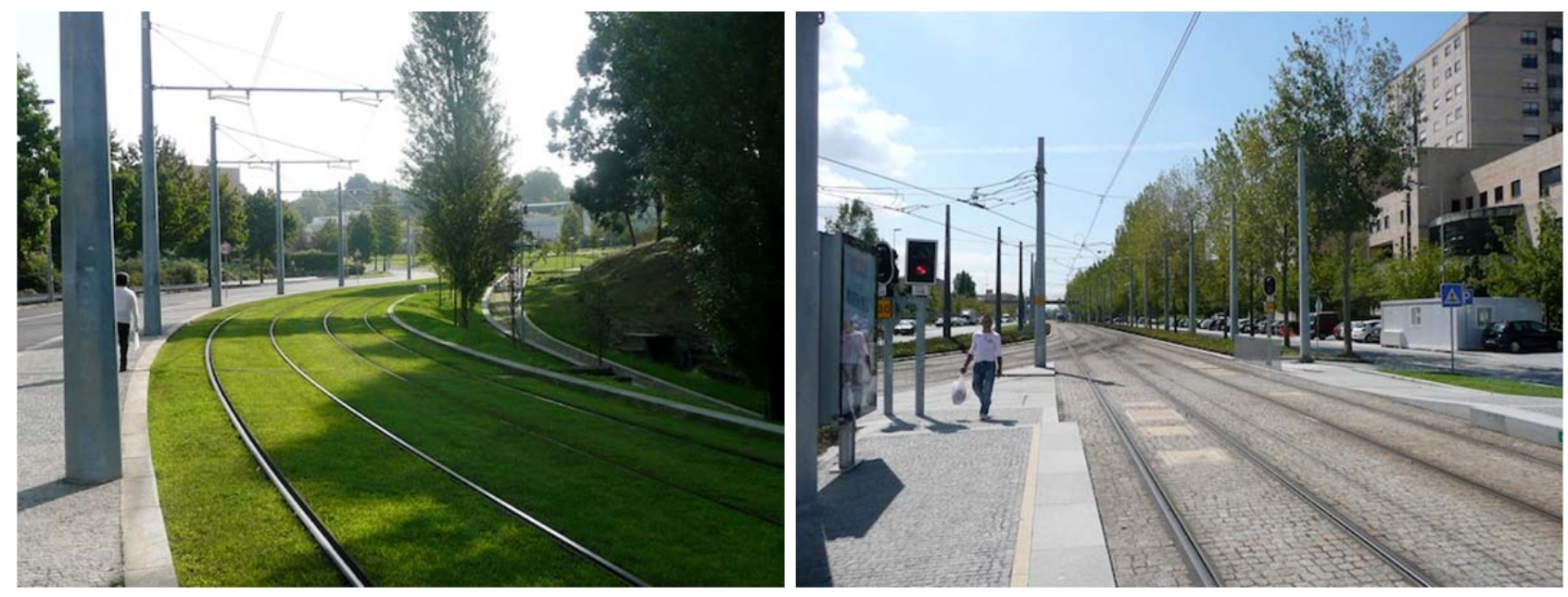

Fig. 3-4. Metro do Porto interventions at Matosinhos. Eduardo Souto de Moura and José Bernardo Távora Source: author

The common design, and the constructive logic as key factors of public space legibility

Directly grounded on the constructive logic assumed by the infrastructure itself, the materialisation of the Metro project has, in our view, the virtue of introducing a "sober" and "coherent" lexicon and principles of design of public space in the city and in the territory.

Using "elements of urbanisation" endowed with a technical and constructive rationality (with the aim of achieving common and generalizing rules, and a formal stability in the design of public space - integrated in an infrastructural system), the Metro do Porto intervention creates a urban quality that spreads across the territory by resorting to a coherent and judicious design synthesis (based on a systematic repetition of standard elements, and on the use of noble materials, designed for heavy use, and to last in time). The Metro do Porto interventions - essentially designing ground - therefore establishes architectural and urban design principles and methodologies that mainly articulate and promote functional and formal continuities. These principles imply that, as a rule, the problems are solved, in a pragmatic way, always having technical, urbanistic, and architectural and construction criteria (taking into account the design solutions that lead to a common and recognizable order) as a fundamental basis for decision-making and action.

The manifestation of beauty and urban consistency of the first phase of the Metro do Porto largely lies in this coherence, unity, solidity, urban significance and accurate characterisation of the redesigned public space. 
From this point of view, we believe that it was in the more indefinite or un-characterised areas where the intervention of the Metro left greater results; since it is in these areas that the elements that characterise the reclassified urban (public) space, acting as ordering components of (re)urbanisation, provide the structure and urbanity level that these areas were lacking.
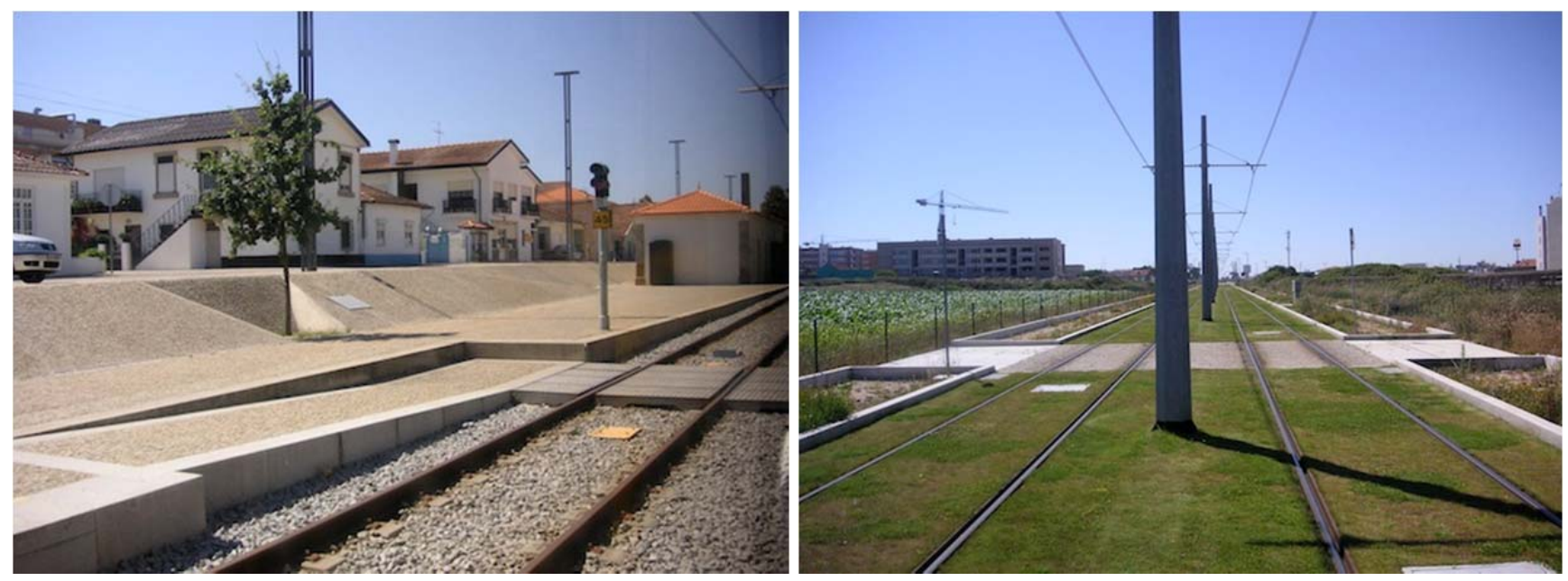

Fig. 5-6. Metro do Porto interventions in Maia (Eduardo Souto de Moura and João Álvaro Rocha) and Vila do Conde (Eduardo Souto de Moura and José Gigante).

Source: author.

\section{Final considerations: on the need to strengthen the consistency and objectivity of the design of public space}

After about a decade since the completion of the first works, the analysis of the Metro do Porto first phase's interventions allow us to consider that the cities that integrate the Porto Metropolitan Area and the metropolitan area as a whole, underwent their greatest transformation, within the recent decades, with the "Metro operations".

The magnitude of change and innovation lies, above all, in the key role that disciplinary knowledge and architectural/urban design practice played in the guidance of the processes of construction /design of the contemporary city and territory, as we know it - increasingly fragmented in technically, politically and economically terms.

The (public space) project, sometimes regarded as "unnecessary" and "impossible," recovers a broaden legitimacy in the Metro do Porto intervention, which allows us to underline the need to provide (and claim) a further design approach consistency, that is able to centralise decisions regarding the project of public space; we are thus defending a design approach that leads to a spatial coherent synthesis, which, in most cases, we believe Architecture is most well suited for to perform (and overwrite the purely functional, opportunistic urban design approach, which is understood, in many cases, as a sum of several technical projects).

In this sense, the example of the Metro do Porto reattaches the public space project to the management and decisions of the city's building processes, surpassing the vision of public space as a mere exercise of an open space design (or as a response to a generic program of use or set of needs). 
This intervention demonstrates the need for a more consistent disciplinary commitment in the construction of public space, in order to recover "a culture of the project" for the city. Based on a more unitary and articulated vision of urban space, capable of restoring some of the features that can be associated with a "way of thinking and constructing" the open public spaces that lasted until the mid-twentieth century: simplicity and efficiency in the design of its components; sobriety in the definition of materials; regularity in formal and technical options, and, finally, but not least, the coordination of the other actors involved in the pursuit and respect for the established purposes.

In conclusion, it can be stated that in the Metro do Porto's case, the ground outcomes demonstrate the ability for an intervention with these characteristics (which in its origin, relates to the design of an infrastructure that "supports movements" and seeks to improve the coordination of the flow of people and vehicles) to become a common urban reference that is already part of the collective memory and which was able to regenerate and articulate the urban complexity and diversity.

It is therefore crucial that the forthcoming projects for the whole Porto Metropolitan Area do not overlook the Metro do Porto interventions as an urban re-foundation moment; that is to say, it is important that the forthcoming projects should recognise the structuring force of the Metro interventions as a fundamental backbone that is able to positively promote the future development of the city.

\section{Notes}

(I) de Solà-Morales, Manuel (2010) "The Impossible Project of Public Space" in In favour of public space: ten years of the European prize (Magda Anglès ed.), Barcelona: Actar, p. 27.

(2) Portas, Nuno "Planeamento Urbano: Morte e Transfiguração" in Arquitectura(s): teoria e desenho, investigação e projecto. Porto: Faup publicações, 2005, pp. 64, 65.

(3) Martí Aris, Carlos (2012) "Lugares Públicos en la Naturaleza", Conference held at Faculdade de Arquitectura do Porto on November 18, 2002, polycopied author's edition, pp. I.

(4) Borja, Jordi; Muxi, Zaida, El espacio público: ciudad y cuidadania, Barcelona: Electa, 2003, p. 57.

(5) Bernardo Secchi quoted by Carlos Martí in "Public Places", Conference held at the Colegio de Arquitectos de Madrid on April 26, 200I, polycopied author's edition, p. I.

Joan Busquets supports this understanding of Bernardo Secchi, when he stresses the need to think the [master] plan as the "(...) container project capable of providing an overview, but also of decanting consensus regarding basic criteria, that may be developed by interventions or projects of very distinct times, but able to open new procedures on unpredictable topics" Joan Busquets (2004).

"Presente y perspectivas del urbanismo", Sociedade e Território, n. 37-38, p. 52.

(6) Carlos Martí in "Public Places", Conference held at the Colegio de Arquitectos de Madrid on 26-04-200I, polycopied author's edition, p. I.

(7) Mindful of this, Joan Busquets stresses the need to rescue the idea of "project, or mediumterm vision plan" from the intervention on "some spaces, in certain systems, or on certain strategies," which, as he states, implies the necessity to study "almost everything" and extensively. This vision is, according to Busquets, directly related to the requisite of recovering the "(...) conceptual and abstract [determination] of the master plan, as a way to address the issue of urban form, without having to fall into the fallacy of designing all its parts (...)". Busquets J. (2005). "Entrevistas: 20 visiones" in Papers. Regió Metropolitana de Barcelona, n. 43, June 2005, pp. 26, 27.

(8) Joan Busquets is one of the authors who have more consistently upheld the "high degree of operability" of the intermediate scale urban project, as privileged instrument of intervention in 
the city. In his view, this instrument corresponds to a “(...) type of urban project that accepts working from the urban fragment, understanding that, from it, it becomes possible to tackle general questions of the city "facing"(...) varied programs where the idea of integration (between infrastructure and city, between public and collective spaces) becomes the fundamental concept". On the other hand, Busquets stresses the importance of the intermediate scale as the most apt in thinking on "inbetween relationships", as it ensures the recognition and enhancement of "propositional ideas in an abstract layer, making them adaptable to different programs and changes in the course of the project. Busquets, Joan (2004). "Presente y perspectivas del urbanismo", Sociedade e Território, n. 37-38, pp. 5I, 52.

(9) de Solà-Morales, Manuel, (1987)."'La segunda historia del proyecto urbano" UR n. 5, pp. 22.

\section{References}

Fernandes F., Cannatà M. (ed.).(2006). A arquitectura do Metro, obras e projectos na Área Metropolitana do Porto. Porto: Civilização.

Aymonino A., Mosco V. P. (2006). Contemporary Public Space. Un-volumetric Architecture. Milano: Skira.

Acebillo J. A. (1989). "Struttura e significato dello spazio urbano". In Spazi Pubblici Contemporanei. Inovazione e identità a Barcelona e in Catalogna". Quaderni di AU, pp. 28-36.

Bohigas O. (1999). "La Cuidad como Espacio Proyectado". In La Arquitectura del Espacio Público: Formas del Passado, Formas del Presente. Sevilha: Junta de Andalucia - Consejería de Obras Públicas y Transportes e Triennale di Milano, pp. 2I-24.

Bohigas O. (2004). Contra la incontinencia urbana: reconsideración moral de la arquitectura y la ciudad. Barcelona: Electa (Diputació de Barcelona; Xarxa de Municipis).

Borja J., Muxi Z. (2003). El espacio público: ciudad y cuidadania. Barcelona: Electa.

Busquets J. (2004). "Presente y perspectivas del urbanismo". In Sociedade e Territorio, n. 37-38, pp. 46-60.

Busquets, J., Correa F. (2006). Cities $X$ Lines: A new lens for the urbanistic project. Cambridge: Harvard University (Graduate School of Design). Nicolodi.

Busquets J. (2005). "Entrevistas: 20 visiones". In Papers. Regió Metropolitana de Barcelona, n. 43, Junio, Pp. 26, 27.

Tapparelli C. (2006). "Cambiare la città...pezzo dopo pezzo", interview to Eduardo Souto de Moura, Casabella. $739-740$ (December 2005 - January 2006), pp. II6-II7.

Huet B. (1999). "Tre questioni a proposito della forma urbana”.In Questioni di forma... urbana. La composizione dello spazio pubblico nel rinuovo della città. Firenze : Alinea, Pp. 5-9.

Innerarity D. 2006). El Nuevo espacio público. Madrid: Espasa-Calpe.

Martí Aris C. (2005). "Lugares Públicos en la Naturaleza”. In La Cimbra y el Arco. Barcelona: Fundación Caja de Arquitectos, pp. 55-72.

Martí Aris C., "Lugares Públicos". Conference held at Colegio de Arquitectos de Madrid, April 26, 200I, policopied author's edition.

Martí Aris C., (1999). "la Construcción de los Lugares Públicos, Notas para una Etimologia de la Forma Urbana". In Arquitectos n. I52, Información del Consejo Superior de los Colegios de Arquitectos de España n. 99/4, V Bienal de Arquitectura Española, pp. 52-57.

Portas, N. (1999). "Espacio público y ciudad emergente". In La Arquitectura del Espacio Público: Formas del Passado, Formas del Presente. Sevilha: Junta de Andalucia - Consejería de Obras Públicas y Transportes e Triennale di Milano, pp. 55-57.

Secchi B. (2000). Prima lezioni di urbanistica. Roma: Laterza.

Secchi B. (2006). "Land design 2". In Contemporary Public Space. Un-volumetric Architecture. Milano: Skira, pp. 287-29I.

Solà-Morales M. (1987). “La segunda historia del proyecto urbano” In UR, n. 5, pp. 2I-27.

Solà-Morales M. (2008). De cosas urbanas. Barcelona: Gustavo Gili. 
Designing the city from public space

Solà-Morales M. (2010). "The Impossible Project of Public Space”. In Magda Anglès (ed.), In favour of public space: ten years of the European prize. Barcelona: Actar, pp. 24-32.

Souto de Moura, E. (2006). "Projecto de Arquitectura para o Metro do Porto". In Fátima Fernandes, Michele Cannatà (ed.), A arquitectura do Metro, obras e projectos na Área Metropolitana do Porto. Porto: Civilização, p. 3I. 